ÖKOLOGISCHE PERSPEKTIVEN FÜR WISSENSCHAFT UND GESELLSCHAFT

ECOLOGICAL PERSPECTIVES FOR

SCIENCE AND SOCIETY

$2 \mid 2009$
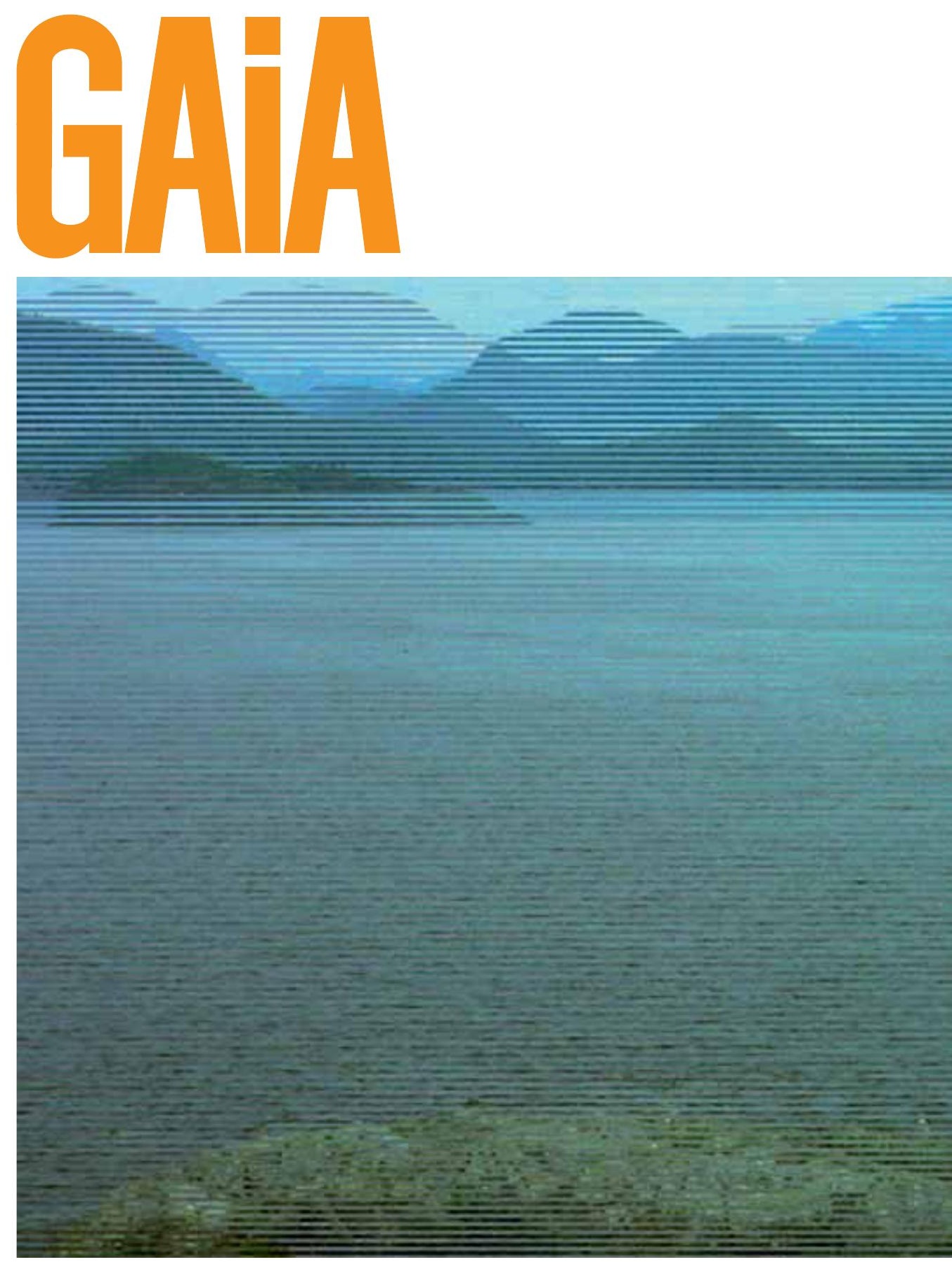

- FOCUS: COASTAL CHANGE AND MANAGEMENT

FOCUS: SYSTEMIC RISKS, PART 2

FINANZ- UND KLIMAKRISE

\footnotetext{
/IIl oekom

GAIA is available online at www.ingentaconnect.com/content/oekom/gaia 


\section{Marine Aquaculture within Offshore Wind Farms: Social Aspects of Multiple-Use Planning}

Combining offshore wind farms and marine aquaculture is a potential means of enhancing spatial efficiency and providing supplementary livelihood options for fishermen. This innovative approach faces up to the challenge of moving aquaculture operations offshore. However, many obstacles still need to be

Tanja Michler-Cieluch, Gesche Krause, Bela H. Buck overcome, not least the provision of a legal framework that would allow for multiple use and management in offshore locations.

\section{Marine Aquaculture within Offshore Wind Farms: Social Aspects of Multiple-Use Planning GAIA 18/2 (2009): 158-162}

\begin{abstract}
Combining offshore wind farming and marine aquaculture is an opportunity to share stakeholder resources and can lead to greater spatial efficiency in the offshore environment. Although biological and technical studies have demonstrated the general feasibility of this approach, a number of complex socioeconomic and technical challenges still need to be dealt with. Focusing on selected social aspects of multiple offshore use, this paper presents a short overview of recent research results on the potential and problems of wind farm-mariculture integration in the German Bight.
\end{abstract}

\section{Keywords}

German Bight, marine aquaculture, multiple-use areas, offshore wind farms, social aspects
T he sustainable development of the German North Sea coast as a living, working, and recreational place is one of the key issues of the joint research project Coastal Futures (Kannen 2004) funded by the German Ministry of Education and Research (Bundesministerium für Bildung und Forschung, BMBF). At present, the multifaceted use of the coastal zone by highly diverse stakeholder groups leads to competing interests for resources and especially space (BMVBS and BBR 2006, p. 36). Planned large-scale offshore wind farms as well as designated marine protected areas (MPAs) are prime examples for the development of permanent marine structures that take up a surface area of several square kilometres each (BMVBS and BBR 2006, p. 35, BSH 2009). In the German Bight of the North Sea these planned structures compete with shipping, recreational activities, cables and pipelines, military exercises, and fisheries (Wirtz et al. 2003, Buck et al. 2004, BSH 2009). At the same time, the increasing demand for highquality foods worldwide accelerates the development of marine aquaculture (see box), which can be expected to become an additional competitor in German offshore waters (Buck et al. 2008). Conflicts amongst the respective user groups are preordained.

\section{Marine Aquaculture}

Marine aquaculture (mariculture) is the cultivation of aquatic organisms in brackish or marine environments. The term "offshore aquaculture" is used to describe the cultivation of organisms in an environment fully exposed to all kinds of sea states (Ryan 2005).

In an effort to maximise the availability of open ocean space for future development, and to facilitate a transition from spatial conflict to spatial efficiency, it has been proposed to combine the emerging industries of offshore wind farming and mariculture. Blue mussel (Mytilus edulis) and sugar kelp (Laminaria saccharina), a macroalgae species, have been identified as most suitable for offshore cultivation in the North Sea (Buck 2002). This paper presents a short review of the current research activities on the 
potential multiple-use setting in the German Bight. Working against the background of social and institutional human dimensions (Charles and Wilson 2009) we place particular emphasis on the interrelationship between scientific findings on the one hand and effective implementation on the other. Key aspects include the social acceptance of combined use, as well as possible management strategies that would govern it.

\section{Prospects and Constraints of Wind Farm- Mariculture Integration}

Key incentives for combining marine aquaculture with offshore wind farming can be summarised as follows:

- Placing mariculture devices in defined corridors between the turbines reduces the need for additional ocean space (see figure). At the same time, the revenue per unit sea area could be maximised by twofold economic use of ocean territories (Michler and Kodeih 2007).

- Infrastructure for regular servicing may be shared. From an operational perspective, wind farms may thus be ideal sites for co-use with aquaculture (Buck et al. 2004).

- Offshore areas such as our case study region in the German North Sea are high-energy environments that are fully exposed to weather, currents, and waves. One of the main diffi- culties in developing offshore cultivation techniques is the need to withstand these harsh hydrodynamic conditions of open ocean exposure (Bridger and Costa-Pierce 2003). Anchoring mariculture devices to wind turbine foundations could be could be a cost-effective solution to this specific problem (Buck et al. 2006).

- Cultivating mussels within offshore wind farms, and becoming mariculture operators themselves, could offer a way for mussel fishermen to secure their business in the long term. Socially, this is an important issue because the high protection status of the Wadden Sea Area, as well as the significant decrease in the natural mussel population, places considerable constraints on traditional mussel fisheries (CWSS 2008). In order to achieve the stated conservation goals, large areas of the Wadden Sea will continue to be closed to mussel fishing. At the same time, it has become clear that the area currently available for nearshore mussel cultivation will not be extended. The search for additional cultivation sites such as offshore is therefore timely.

Ecologically, mussels filter plankton and other particulate matter whilst macroalgae extract nutrients directly from the water column. Their cultivation in offshore locations is expected to be environmentally sound as little interference with the environment is anticipated except for nutrient extraction and plankton grazing (Buck 2004).



FIGURE: Future vision of joint wind farm- 
However, prospective wind farm-mariculture integration within so-called multi-purpose marine areas will only gain widespread acceptance if the respective activities do not interfere with one another technically, operationally, or commercially and if benefits can be ensured to both parties.

A significant body of research is now becoming available on practical biological and physical-technical issues that arise from potential wind farm-mariculture integration in the German Bight. To a lesser extent this also applies to social science research, which focuses on selected economic, institutional, and managementoriented aspects. Most of the available literature is reviewed in Buck et al. (2008). So far Germany is leading in this rather recent field of research. It is therefore impossible to draw on experiences from other countries interested in this kind of combination such as Denmark, the Netherlands, Belgium, or Scotland. The main results and the potential problems identified for wind farmmariculture integration can be summarised as follows:

Biological and physical-technical domain: Overall results reveal excellent growth rates and satisfactory settlement success for mussel larvae in different offshore locations in the North Sea. No parasite infestation in mussels is found, and technical solutions exist to facilitate the cultivation of mussels and algae. However, problems remain in how to cope with the additional mechanical load for wind turbine foundations that may result if aquaculture structures were anchored to them. As stated above, the German Bight is a high-energy environment, and aquaculture structures (long lines, see figure) would be abundantly covered in biomass. As such, mechanical load can easily be considered a key boundary condition. Anchoring mariculture devices to renewable energy systems is likely to require use of special materials, and additional cost-intensive risk calculations and safety measures will be necessary (Buck et al. 2008). Although solutions could be conceived that are technically and economically feasible, the necessary changes to wind turbine foundations could alter their properties to such a degree that ongoing licensing procedures might have to be re-started. An alternative would be to construct special mariculture anchoring devices between the wind turbines. While still serving the goal of spatial efficiency, this would partly reduce the economic advantages of co-use.

In order to fill the remaining knowledge gaps in this field, recent research has focused on a) technical implementation, in particular the technical implications of aquaculture requirements for turbine foundation design (Buck et al. 2006), b) overall physical and oceanographic conditions (Buck and Buchholz 2005), c) biotic parameters such as phytoplankton and nutrient availability (Buck 2004, Walter et al. submitted) as well as the overall health status of blue mussel and its use as an indicator in selecting potential offshore cultivation areas (Brenner et al. submitted).

Economic domain: First results show that the service life of infrastructure used for offshore cultivation, together with the mussel yield obtained per culture unit, is amongst the most crucial factors determining profitability of seed mussel cultivation in off- shore locations (Buck et al. 2008). However, calculating the economic efficiency of offshore aquaculture in the German Bight is difficult since there are no absolutely reliable data on overall investment, operation, and production costs as well as actual returns (Buck and Michler-Cieluch submitted). Since environmental costs and benefits are equally difficult to determine, calculating the economics of mussel farming in the context of offshore wind farms will only be best estimates. To actually engage the respective stakeholder groups in this form of multiple use, however, confirmation of economic feasibility is a prerequisite (Buck et al. 2008, Michler-Cieluch and Krause 2008).

Management-institutional domain: Co-management arrangements could be a solution for governing wind farm-mariculture integration (Michler-Cieluch et al. 2009). Co-management makes use of the capacities and interests of the respective actor groups and employs these in managing cross-sectoral activities in cooperation with governmental authorities. To address the respective technical, economic, social, and political challenges of mariculture and offshore wind, specific co-management strategies are needed that are either more results-oriented (e.g., for integrating technical knowledge of the two sectors) or more process-oriented (e.g., for establishing new linkages between different groups) (Michler-Cieluch and Krause 2008).

At the same time, relevant authorities at all levels need to develop and implement a policy of multiple use and establish the necessary legal framework that will enable offshore energy systems and mariculture to be integrated (Michler-Cieluch and Krause 2008). The recent marine spatial planning approach developed for the German Exclusive Economic Zone (EEZ) is a new policy instrument that acknowledges this form of co-use: Specific mention is made of the fact that offshore turbine foundations could be used for anchoring mariculture facilities (BMVBS 2009, p. 42). Whether this is enough of a stimulus to truly engage the relevant actors in multiple-use planning remains to be seen.

The above makes clear that all of these issues require equal priority since every one can cause significant delays in the implementation of multiple offshore use.

\section{Our Study: Social Aspects of Multiple Offshore Use}

As was shown in the literature review, planning, implementing, and managing future wind farm-mariculture integration need to take into account the social aspects of multiple offshore use. In particular, this refers to stakeholder objectives, attitudes, and knowledge. As evident from the policy surrounding MPA implementation (Charles and Wilson 2009), consideration of these aspects can enhance acceptance and lead to better performance.

We carried out a questionnaire survey of representatives of the two potential adopter groups in Germany. These were "offshore wind farms" and "coastal fisheries", with the latter comprising the 
members of the German mussel fishery society. Despite of a considerable interest in the idea of co-use in both groups, there still is a healthy degree of scepticism as far as feasibility is concerned (Michler-Cieluch and Kodeih 2008). The concerns expressed by wind farm developers/operators mostly relate to the potentially negative impacts of mariculture on the operation of the wind farm, as well as loss of site integrity. Members of the mussel fishery society primarily point to the (many) economic and technical challenges that still have to be overcome in the context of offshore cultivation (see table). Results obtained from in-depth interviews with international decision-makers and practitioners from both sectors support these findings. German interviewees also called into question whether adequate arrangements could be made that guarantee successful cooperation with the other party. This particularly applies to commercial use and to questions of insurance (Michler-Cieluch and Krause 2008). The results also revealed that the coastal fishery society has reasons for opposing the installation of offshore wind farms independent of co-use (mainly fear of loss of fishing grounds), which colour their attitude to the multiple-use setting suggested (Michler-Cieluch and Kodeih 2008).

Overall, the concerns revealed in our surveys either relate to socio-cultural issues, to policy issues, or to issues of economic and technical feasibility. The potential for conflict between the two groups is therefore as varied as it is complex.

However, our results also show that the actors in the two user groups can make a significant contribution towards the success of future multiple-use concepts. Understanding their objectives and attitudes as well as their values is crucial if complex problems are to be resolved. It is well known that actor groups directly involved in or affected by innovations exert great influence on new developments and can even imperil entire projects (Tango-Lowy and Robertson 2002, Apt and Fischhoff 2006).

In order to develop suitable management strategies as well as the policy framework needed to govern multiple ocean use, the significance of all these social factors needs to be acknowledged (Michler-Cieluch and Krause 2008, Michler-Cieluch and Kodeih 2008). Key leaders or groups of key leaders may be required to establish the functional links within and between the participating actor groups and to develop the necessary social networks for the context of multiple offshore management (Olsson et al. 2004). It is likely that these key figures will need to come from within the respective "offshore society" and will clearly need to be accepted by all of its members.

\section{Conclusion and Outlook}

The review of available literature shows that the combination of offshore wind farming and marine aquaculture on the German North Sea coast could yield economic and ecological as well as social benefits in the near future. However, more baseline assessments are needed to pinpoint the specific potentials of such integration and to ensure that wind farm developers/operators, mussel harvesters, and administrative bodies can effectively translate research outcomes into practical application. To deal with the concerns that still surround the implementation process, and to render the rather abstract topic of multiple-use management more tangible, small-scale pilot projects testing different options (e.g., in terms of anchoring) need to be established involving all parties in a process of iterative problem solving. Doubters in par-

TABLE: Statements made by offshore wind farming and fisheries representatives on the potential of wind farm-mariculture integration (adapted from MichlerCieluch and Kodeih 2008, where the methodology is described as well; the original table includes statements of two more coastal actor groups).

\begin{tabular}{|c|c|}
\hline actor group & statements \\
\hline \multicolumn{2}{|l|}{ fisheries } \\
\hline statements in support & $\begin{array}{l}\text { " "Co-use) is not an alternative to mussel fishery but an additional possibility. Synergetic effects are always desirable." } \\
\text { "Could open up interesting possibilities and have advantages for both wind farmers and fishermen." }\end{array}$ \\
\hline critical statements & $\begin{array}{l}\text { " "There are no reliable original data." } \\
\text { "There is still the issue of loss of fishing grounds. Mariculture of this kind is not economical and does not represent an } \\
\text { alternative to sea fishing." } \\
\text { " "Too little mussel spat is available in the region, I think it will stay a fantasy." } \\
\text { " "It's a ploy to show offshore wind farms in a better light and to enhance public acceptance." }\end{array}$ \\
\hline \multicolumn{2}{|l|}{ offshore wind energy } \\
\hline statements in support & $\begin{array}{l}\text { "New innovative idea, although there are many open questions to be resolved such as technical feasibility or the problem of } \\
\text { cross-linking of branches." } \\
\text { "Additional uses are welcome, also for the purpose of increasing acceptance among fishermen." } \\
\text { " "(Co-use represents a) maximisation of the economic value of ocean territory from an ecological point of view." }\end{array}$ \\
\hline critical statements & $\begin{array}{l}\text { "I don't see any added value for manufacturers/suppliers of windmills or for the operators. The use of offshore wind energy } \\
\text { has nothing to do with mariculture." } \\
\text { "Attaching (mariculture devices) to turbine foundations could be a problem and requires third-party certification." } \\
\text { " "The problem will be to ensure that operation and maintenance of the wind turbines is not impeded." }\end{array}$ \\
\hline
\end{tabular}


ticular should be involved in any final assessment. To set up pilot projects, however, offshore wind farms need to be constructed in the first place. The process has experienced long delay due to the very complex licensing procedures and significant environmental constraints. Ultimately, though, policy-makers are tasked with providing the necessary political and legal framework - a framework that is able to facilitate multiple uses offshore and leads to integration of multidisciplinary research outcomes.

\section{References}

Apt, J., B. Fischhoff. 2006. Power and people. The Electricity Journal 19: 17-25. BMVBS (Bundesministerium für Verkehr, Bau und Stadtentwicklung). 2009. Entwurf-Verordnung über die Raumordnung in der Deutschen Ausschließlichen Wirtschaftszone (AWZ-ROV). 28. April 2009. Berlin: BMVBS.

BMVBS, BBR (Bundesamt für Bauwesen und Raumordnung). 2006. Integriertes Küstenzonenmanagement (IKZM): Raumordnungsstrategien im Küstenbereich und auf dem Meer. Abschlussbericht. Berlin: BMVBS.

Brenner, M., S. Ramdohr, S. Effkemann, M. Stede. Submitted. Key parameters for the consumption suitability of offshore cultivated blue mussels (Mytilus edulis L.) in the German Bight. Journal of European Food Research and Technology. Bridger, C. J., B. A. Costa-Pierce (Eds.). 2003. Open ocean aquaculture: From research to commercial reality. Baton Rouge, LA: World Aquaculture Society.

BSH (Bundesamt für Seeschifffahrt und Hydrographie). 2009. CONTISGeodata. Hamburg: BSH. www.bsh.de (accessed February 28, 2009).

Buck, B. H. 2002. Open Ocean Aquaculture und Offshore-Windparks: Eine Machbarkeitsstudie über die multifunktionale Nutzung von Offshore-Windparks und Offshore-Marikultur im Raum Nordsee. Reports on Polar and Marine Research, Alfred Wegener Institute for Polar and Marine Research (AWI), 412. Bremerhaven: AWI.

Buck, B. H. 2004. Farming a high energy environment: Potentials and constraints of sustainable offshore aquaculture in the German Bight (North Sea). PhD dissertation. Bremen: University of Bremen.

Buck, B. H., A. Berg-Pollack, J. Assheuer, O. Zielinski, D. Kassen. 2006. Technical realization of extensive aquaculture constructions in offshore wind farms: Consideration of the mechanical loads. In: Proceedings of the $25^{\text {th }}$ International Conference on Offshore Mechanics and Arctic Engineering, OMAE 2006. 4-9 June 2006, Hamburg, Germany. Edited by the American Society of Mechanical Engineers. 1-7.

Buck, B. H., C. M. Buchholz. 2005. Response of offshore cultivated Laminaria saccharina to hydrodynamic forcing in the North Sea. Aquaculture 250: 674-691.

Buck, B. H., G. Krause, H. Rosenthal. 2004. Multifunctional use, environmental regulations and the prospect of offshore co-management: Potential for and constraints to extensive open ocean aquaculture development within wind farms in Germany. Ocean Q Coastal Management 47/3-4: 95-122.

Buck, B. H., T. Michler-Cieluch. Submitted. Mussel cultivation as a co-use in offshore wind farms: Potentials and economic feasibility. Aquaculture Economics and Management.

Buck, B. H. et al. 2008. Meeting the quest for spatial efficiency: Progress and prospects of extensive aquaculture within offshore wind farms. Helgoland Marine Research 62/3: 269-281.

Charles, A., L. Wilson. 2009. Human dimensions of Marine Protected Areas. ICES Journal of Marine Science 66/1: 6-15.

CWSS (Common Wadden Sea Secretariat). 2008. Nomination of the Dutch-German Wadden Sea as World Heritage Site. Volume 1. Wilhelmshaven: CWSS.

Kannen, A. 2004. Holistic systems analysis for ICZM: The Coastal Futures approach. In: Coastline reports 1. Geography of seas and coasts. Edited by G.S. Schernewski, T. Dolch. Warnemünde, Germany: EUCC - The Coastal Union. 171-181.

Michler, T., S. Kodeih. 2007. Integration of mariculture in offshore wind farms. Coast Line Magazine 16: 8.

Michler-Cieluch, T., S. Kodeih. 2008. Mussel and seaweed cultivation in offshore wind farms: An opinion survey. Coastal Management 36/4: 392-411.
Michler-Cieluch, T., G. Krause. 2008. Perceived concerns and possible management strategies for governing "wind farm-mariculture integration". Marine Policy 32/6: 1013-1022.

Michler-Cieluch, T., G. Krause, B. H. Buck. 2009. Reflections on integrating operation and maintentance activities of offshore wind farms and mariculture. Ocean \& Coastal Management 52/1: 57-68.

Olsson, P., C. Folke, F. Berkes. 2004. Adaptive comanagement for building resilience in social-ecolocial systems. Environmental Management 34/1: 75-90.

Ryan, J. 2005. Offshore aquaculture - Do we need it, and why is it taking so long? Paper presented at the IPTS Expert workshop on Sustainable Aquaculture, Directorate-General Joint Research Centre European Commission, Institute for Prospective Technological Studies (IPTS). Seville, January 17-18.

Tango-Lowy, T., R. A. Robertson. 2002. Predisposition toward adoption of open ocean aquaculture by Northern New England's inshore, commercial fishermen. Human Organization 61/3: 240-251.

Walter, U., B. H. Buck, G. Liebezeit. Submitted. Larval occurrence and settlement in the German Bight - a trial to estimate potentials for Mytilus edulis culture in offshore areas. Aquaculture International.

Wirtz, K. W., R. S. J. Tol, K. G. Hooss. 2003. Mythos „Offene See“: Nutzungskonflikte im Meeresraum. In: Warnsignale aus Nordsee Q Wattenmeer. Eine aktuelle Umweltbilanz. Edited by J. Lozán, E. Rachor, K. Reise, J. Sündermann, H. von Westernhagen. Hamburg: Wissenschaftliche Auswertungen. 157-160.

Submitted March 15, 2009; revised version accepted April 27, 2009.

Tanja Michler-Cieluch

Born 1972 in Gehrden, Germany. Diploma in biology and M. Sc. in Integrated Coastal Zone Management (ICZM), University of Oldenburg. Since 2004 scientific research at the Alfred Wegener Institute for Polar and Marine Research (AWI), Bremerhaven, on offshore co-management processes

and governance schemes to integrate offshore wind farm and mariculture activities in the North Sea. Currently in the final stage of her doctoral thesis at the University of Hamburg. Main fields of interest: integrated coastal management (ICM), multiple offshore use, stakeholder perspectives, marine policy.

Gesche Krause

Born 1969 in Kiel, Germany. Diploma in geography from the University of Kiel, and PhD in Natural Resource Management from Stockholm University. Since 1997 scientific research at the Centre for Tropical Marine Ecology (Zentrum für Marine Tropenökologie, ZMT), Bremen,

on Integrated Coastal Zone Management (ICZM) and governance issues; social-ecological system research and identification of resulting co-evolutionary patterns in Brazil and Indonesia. Consultancy for the EU on ICZM. Main fields of interest: ICZM, social-ecological systems analysis, marine aquaculture, social dimensions of resource use.

Bela H. Buck

Born 1968 in Mülheim (Ruhr), Germany. Studies of marine biology at the University of Bremen, at the Institute for Marine Research, Kiel, the Centre for Tropical Marine Ecology (Zentrum für Marine Tropenökologie, ZMT), Bremen, and the James Cook University, Townsville (Australia). PhD at the Alfred Wegener Institute for Polar and Marine Research (AWI), Bremerhaven, and the University of Bremen on offshore aquaculture technology, biology, legislation, and Integrated Coastal Zone Management (ICZM) within the German North Sea. Since July 2007 cooperation professorship for Applied Marine Biology at the University of Applied Sciences Bremerhaven and the AWI. Main fields of interest: marine aquaculture, maritime technologies, applied marine biology. 